\title{
PENERAPAN STRATEGI SEGMENTASI PASAR DAN POSITIONING PRODUK DENGAN PENDEKATAN ANALISIS SWOT UNTUK PENINGKATAN PENJUALAN PADA UD. SURYA GEMILANG MOTOR DI SURABAYA
}

\author{
*(Yunni Rusmawati Dj. \\ Fakultas Ekonomi \\ Universitas Islam Lamongan
}

\begin{abstract}
ABSTRAK
Penggunaan analisis SWOT merupakan salah satu alat yang dapat dipakai untuk mengetahui keunggulan dan kelemahan suatu perusahaan khususnya di bidang pemasaran. Analisis SWOT merupakan singkatan dari lingkungan internal kekuatan (strengths) dan kelemahan (weakness) serta lingkungan eksternal peluang/ kesempatan (opportunities) dan ancaman (threats) yang dihadapi dunia bisnis. Lingkungan eksternal perusahaan setiap saat berubah dengan cepat sehingga melahirkan berbagai ancaman dan peluang yang datang dari pesaing maupun iklim bisnis yang berubah. Konsekuensi dari perubahan faktor internal tersebut mengakibatkan berubahnya faktor internal perusahaan, seperti perubahan terhadap kekuatan maupun kelemahan perusahaan. Penerapan segmentasi pasar dan positioning produk yang tepat dan efektif dapat menunjang keputusan konsumen dalam pembelian produk. Hal tersebut dilakukan perusahaan agar berhasil dalam mencapai tujuannya. Tujuan penelitian ini adalah untuk mengetahui bagaimana penerapan strategi segmentasi pasar dan positioning produk dengan pendekatan analisis SWOT untuk peningkatan penjualan pada UD. Surya Gemilang Motor di Surabaya dan untuk mengetahui bagaimana kebijakan penerapan strategi segmentasi pasar dan positioning produk dengan pendekatan analisis SWOT dapat meningkatan penjualan pada UD. Surya Gemilang Motor. Lokasi penelitian ini bertempat pada UD. Surya Gemilang Motor di Jl. Babat Jerawat 8 Benowo Surabaya. Jenis penelitian yang digunakan yaitu jenis penelitian kualitatif. Berdasarkan hasil penelitian diperoleh dari hasil analisis SWOT penerapan strategi segmentasi pasar dan positioning produk pada UD Surya Gemilang Motor untuk peningkatan penjualan yaitu perumusan strategi yang efektif akhirnya diperoleh strategi agresif SO yaitu strategi kekuatan yang memanfaatkan peluang yang dimiliki perusahaan yaitu 1)Lebih meningkatkan sistem menegemen yang efektif dan efisien. 2)Lebih meningkatkan SDM agar tetap dipercaya konsumen. 3)Menentukan segmen pasar dan positioning produk.
\end{abstract}

Kata Kunci: Segmentasi pasar, positioning produk, Analisis SWOT dan Peningkatan Penjualan. 


\section{PENDAHULUAN}

Perkembangan Dunia usaha pada era globalisasi saat ini semakin ketat dan kompleks, persaingan dan teknologi semakin canggih, globalisasi telah terjadi di semua bidang usaha, bila para pengusaha tidak mengikuti perkembangan zaman maka mereka akan tertinggal dengan perkembangan yang semakin canggih. Oleh karena itu pengusaha dituntut agar selalu berorientasi kemasa depan dan harus jeli mengikuti segala bentuk perubahan dan perkembangan yang terjadi di masyarakat dan perubahan tersebut disesuaikan dengan program organisasi perusahaan tersebut.

Perusahaan tidak terlepas dari berbagai macam perubahan yang bersumber dari lingkungan eksternal maupun lingkungan internal perusahaan. Perubahan yang negative merupakan gangguan bagi perusahaan, sedangkan perubahan yang positif akan dapat menunjang kelangsungan hidup perusahaan. Oleh sebab itu perusahaan harus dapat memperhatikan faktor-faktor yang dapat mempengaruhi kelangsungan hidup perusahaan baik faktor eksternal maupun internal perusahaan.

Strategi untuk menghadapi
lingkungan eksternal dapat
ditetapkan dengan mengetahui apa
yang menjadi ancaman (threaths)
dan apa yang menjadi peluang
(opportunity) bagi perusahaan.
Setelah mengetahui lingkunagn
eksternal yang dihadapi, maka
analisis lingkungan internal juga
perlu dilakukan guna mengetahui apa
yang menjadi kekuatan (stengths)
dan apa yang menjadi kelemahan
(weakness) dari perusahaan. Dengan

demikian perusahaan selalu dapat beradaptasi dengan lingkungannya sehingga upaya untuk mencapai tujuan senantiasa akan dapat tercapai. (Rangkuti, Freddy. 2014:19).

Penggunaan analisis SWOT merupakan salah satu alat yang dapat dipakai untuk mengetahui keunggulan dan kelemahan suatu perusahaan khususnya di bidang pemasaran. Analisis SWOT merupaan singkatan dari lingkungan internal kekuatan (strengths) dan kelemahan (weakness) serta lingkungan eksternal peluang/ kesempatan (opportunities) dan ancaman (threats) yang dihadapi dunia bisnis. Analisis SWOT timbul secara langsung maupun tidak langsung karena adanya persaingan yang datang dari perusahaan lain. Hal ini perusahaan harus menerapkan strategi untuk memenangkan persaingan atau paling tidak hidup di pasar. Perusahaan membutuhkan antisipasi yang tepat sehingga perusahaan mampu memasarkan produknya di pasar. Perusahaan harus menjalankan semua operasinya secara efektif dan efisien tidak terkecuali dibidang pemasaran. (Rangkuti, Freddy. 2014:20).

\section{Pemasaran sebagai suatu} sistem keseluruhan dari kegiatan usaha yang ditujukan untuk memudahkan konsumen dan calon pembeli potensial dalam menetapkan program perusahaan. Perumusan strategi pemasaran didasarkan pada analisis yang menyeluruh terhadap pengaruh faktor-faktor lingkungan eksternal dan internal perusahaan. Lingkungan eksternal perusahaan setiap saat berubah dengan cepat sehingga melahirkan berbagai 
ancaman dan peluang yang datang dari pesaing utama maupun iklim bisnis yang senantiasa berubah. Konsekuensi dari perubahan faktor internal tersebut juga mengakibatkan berubahnya faktor internal perusahaan, seperti perubahan terhadap kekuatan maupun kelemahan perusahaan tersebut. (Rangkuti, Freddy. 2014:101).

Segmentasi pasar merupakan suatu proses membagi pasar secara keseluruhan suatu produk atau jasa yang bersifat heterogen kedalam beberapa segmen dimana setiap segmen bersifat homogen dalam segala aspek. Disamping itu kita harus menempatkan produk di benak konsumen dengan ciri-ciri sehingga dapat membedakannya dengan produk lain yang disebut positioning. Positioning merupakan strategi yang berusaha menciptakan deferensiasi yang unik dalam bentuk pelanggan sasaran sehingga terbentuk citra atau image merk yang lebih unggul di bandingkan yang lain. Positioning berkaitan dengan bagaimana memainkan komunikasi agar dalam benak konsumen tertanam suatu citra tertentu.

\footnotetext{
Posisi produk adalah cara produk didefinisasikan oleh konsumen pada atribut pesaing yang dimiliki atau tempat dimana produk dibedakan dalam benak konsumen dibandingkan dengan produk yang lain. Pembedaan dan pemosisian perlu dilakukan karna banyaknya produk dipasar. Konsumen setiap membeli barang akan banyak sekali pilihan produk sehingga mereka akan sulit mengidentifikasi produk yang sebenarnya akan dibeli. (Suharno. 2010:96)
}

\begin{abstract}
Penjelasan diatas mampu untuk menjawab permasalahan dalam menetapkan strategi apa yang akan digunakan perusahaan untuk meningkatkan penjualan. Penerapan segmentasi pasar dan positioning produk yang tepat dan efektif dapat menunjang keputusan konsumen dalam pembelian produk. Hal tersebut dilakukan perusahaan agar berhasil dalam mencapai tujuannya.

Berdasarkan latar belakang tersebut di atas, maka rumusan masalah dalam penelitian ini sebagai berikut :
\end{abstract}

1. Bagaimana penerapan strategi segmentasi pasar dan positioning produk dengan menggunakan pendekatan analisis SWOT untuk peningkatan penjualan pada UD. Surya Gemilang Motor di Surabaya?

2. Bagaimana kebijakan penerapan strategi segmentasi pasar dan positioning produk dengan pendekatan analisis SWOT dapat meningkatkan penjualan pada UD. Surya Gemilang Motor Surabaya?

Dari perumusan masalah tersebut, maka tujuan dari penelitian ini adalah :

1. Untuk mengetahui bagaimana penerapan strategi segmentasi pasar dan positioning produk dengan pendekatan analisis SWOT untuk peningkatan penjualan pada UD. Surya Gemilang Motor Surabaya.

2. Untuk mengetahui bagaimana kebijakan penerapan strategi segmentasi pasar dan positioning produk dengan pendekatan analisis SWOT dapat 
meningkatan penjualan pada UD. Surya Gemilang Motor Surabaya.

Dari sebuah penelitian tentunya membutuhkan pengertianpengertian untuk menyempurnakan penelitian tersebut.

\section{Pengertian (Pemasaran) \\ Marketing}

Menurut Kotler dan Keller (2004:5) "Pemasaran adalah suatu fungsi organisasi dan serangkaian proses untuk menciptakan, mengkomunikasikan, dan memberikan nilai kepada pelanggan, untuk mengelola hubungan pelanggan dengan cara yang menguntungkan organisasi dan pemangku kepentingannya."

Menurut Swastha dan Irawan (2008:5) Merupakan salah satu dari kegiatan-kegiatan pokok yang dilakukan oleh para pengusaha dalam usahanya untuk mempertahankan kelangsungan hidupnya, berkembang, dan mendapatkan laba.

Berdasarkan pengertian diatas dapat disimpulkan bahwa pemasaran adalah proses pencarian atas apa yang diinginkan dan dibutuhkan konsumen, menyediakan barang dan jasa untuk memenuhi keinginan tersebut dan mengkomunikasikan nilai barang atau jasa, serta penciptaan hubungan dengan pelanggan sehingga dapat menciptakan kepuasan bagi pelanggan dan memberikan laba bagi perusahaan yang bersangkutan.

\section{a. Strategi Pemasaran}

Strategi Pemasaran menurut Philip Kotler (2004:81) adalah pola pikir permasalahan yang akan digunakan untuk mecapai tujuan pemasarannya. Strategi pemasaran berisi strategi spesifik untuk pasar sasaran, penetapan posisi, bauran pemasaran, dan besarnya pengeluaran pemasaran. Strategi pemasaran didasarkan atas 5 konsep strategi sebagai berikut:

\section{1) Segmentasi pasar}

Setiap pasar pasti terdiri dari bermacam-macam pembeli yang mempunyai kebutuhan dan kebiasaan yang berbeda, perusahaan tidak mungkin dapat memenuhi kebutuhan semua pembeli. Karena itu, perusahaan harus mengelompokkan pasar yang bersifat heterogen kedalam satuan pasar bersifat homogen.

\section{2) Market positioning}

Strategi pemasaran yang kedua adalah memilih pola spesifik pasar perusahaan yang akan memberikan kesempatan maksimum kepada perusahaan untuk mendapatkan kedudukan yang kuat, dengan kata lain perusahaan harus memilih segmen pasar yang akan menghasilkan penjualan dan laba yang paling besar.

\section{3) Market entry strategy}

Market entry strategy adalah strategi perusahaan untuk memasuki segmen pasar yang dijadikan pasar sasaran penjualan.

\section{4) Market mix strategy}

Merupakan kumpulan variabelvariabel yang dapat dipergunakan perusahaan untuk mempengaruhi tanggapan-tanggapan konsumen. 


\section{5) Timing strategi}

Penentuan saat yang tepat dalam memasarkan barang, merupakan hal yang perlu diperhatikan. Meskipun perusahaan melihat adanya kesempatan baik untuk menetapkan objek dan menyusun strategi, ini tidaklah perusahaan dapat langsung memulai kegiatan pemasaran. Perusahaan harus melakukan persiapan-persiapan baik dibidang produksi maupun pemasarannya, kemudian perusahaan harus menentukan saat yang tepat untuk memasarkan barang atau jasa kepasaran.

\section{Fungsi Marketing Bagi Perusahaan}

Menurut Kotler (2004:67) beberapa fungsi marketing bagi perusahaan, diantaranya adalah sebagai berikut :

\section{1) Fungsi pertukaran}

Dengan marketing, konsumen dapat membeli produk yang berasal dari produsen baik itu dengan menukar uang dengan produk maupun melakukan pertukaran produk dengan produk untuk digunakan sendiri atau untuk dijual kembali.

2) Fungsi distribusi fisik

Distribusi fisik pada produk dilakukan dengan cara mengangkut daan menyimpan produk. Produk yang berasal dari produsen akan memenuhi kebutuhan para konsumen dan dapat disalurkan melalui darat, air, dan udara.

3) Fungsi perantara

Untuk dapat menyampaikan produk dari produsen kepada konsumen, dapat dilakukan lewat perantara pemasaran atau marketing yang menghubungkan aktivitas pertukaran dengan distribusi fisik.

\section{Konsep Pemasaran}

Menurut Kotler (2001:92) terdapat beberapa konsep pemasaran yaitu:

1) Dapat memenuhi kebutuhan dan keinginan

Kebutuhan tidak dapat diciptakan oleh masyarakat maupun pemasar, akan tetapi mereka merupakan hakikat biologis dan kondisi atau keadaan manusia itu sendiri. Selain itu manusia juga selalu menginginkan berbagai macam hal, agar bisa membuat diri mereka puas.

2) Produk

Produk merupakan penawaran yang dapat dibagi kadalam 3 kategori, yang diantaranya adalah barang, jasa, dan gagasan. Semua produk yang dihasilkan oleh produsen merupakan sesuatu yang ditawarkan kepada konsumen untuk memenuhi kebutuhannya.

3) Nilai, Biaya dan Kepuasan Dalam hal ini tergantung dari pemikiran setiap konsumen terhadap produk yang digunakan untuk memenuhi kebutuhannya.

4) Pertukaran dan transaksi

Jika persyaratan telah disetujui oleh kedua belah pihak , maka pertukaran akan segera terjadi. Pertukaran seharusnya dilihat sebagai suatu proses, jika kedua belah pihak akan menuju kepada kesepakatan, maka transaksi akan terjadi. 
5) Hubungan dan jaringan

Hasil dari pemasaran hubungan yaitu untuk mengembangkan berbagai masam aset yang dimiliki oleh perusahaan yang biasanya disebut dengan jaringan pemasaran. Jaringan pemasaran umumnya terdiri dari perusahaan lagi dan pihak-pihak yang memiliki berbagai macam kepentingan.

6) Pasar

Pasar terdiri dari konsumen atau pembeli yang memiliki kebutuhan tertentu, yang mungkin kebutuhannya tersedia dan mampu melaksanakan pertukaran nilai. Sehingga dapat terjadi transaksi untuk memenuhi kebutuhannya.

7) Pemasar dan calon pembeli

Pemasar merupakan orang yang mencari calon pembeli yang nantinya akan terlibat dalam pertukaran nilai, sehingga calon pembeli dapat terpenuhi. Sedangkan calon pembeli adalah orang yang akan diidentifikasi oleh pemasar dan nantinya mungkin dapat terlibat dalam pertukaran nilai sehingga terjadi transaksi.

\section{Pengertian Harga}

Menurut Swastha \& Irawan (2008:241) Harga merupakan sesuatu yang dibutuhkan untuk mendapatkan sejumlah kombinasi antara pelayanan ditambah produk dengan membayar jumlah uang yang sudah menjadi patokan.

\section{Strategi Penerapan Harga}

Salah satu cara yang dilakukan untuk menarik minat konsumen adalah dengan cara menentukan harga yang tepat untuk produk yang terjual. Harga yang tepat adalah harga yang sesuai dengan kualitas produk suatu barang, dan harga tersebut dapat memberikan kepuasan kepada konsumen. Menurut Purwanto (2013: 79) strategi penetapan harga adalah tahapan dimana perusahaan mengklasifikasikan dan menggolongkan produk atau jasa yang dihasilkannya. Merupakan "produk baru" yang belum memiliki konsumen loyal/tetap atau "produk yang telah beredar" yang telah memiliki pangsa pasar tersendiri. Penjual barang dalam menetapkan harga dapat mempunyai tujuan yang berbeda satu sama lain antar penjual maupun antar barang yang satu dengan yang lain.

\section{Segmentasi Pasar}

$\begin{array}{rrr}\text { Segmentasi } & \text { pasar } \\ \text { menurut } & \text { Tjiptono } & (2008: 69)\end{array}$ adalah proses membagi pasar keseluruhan suatu produk atau jasa yang bersifat heterogen ke dalam beberapa segmen dimana masingmasing segmen cenderung bersifat homogeny dalam segala aspek. Menurut Suharno dan Yudi Santoso, segmentasi pasar adalah membagi pasar ke dalam beberapa kelompok pembeli yang dibedakan kebutuhan, karakteristik,atau tingkah laku yang berbeda yang mungkin membutuhkan produk atau bauran pemasaran yang terpisah.

a. Langkah-langkah segmentasi pasar

Ada beberapa langkah yang dilalui segmenter dalam melakukan segmentasi pasar menurut Tjiptono (2008:71) dalam mengidentifikasi segmen utama dalam suatu prosedur yaitu : 
1) Tahap survey

Perusahaan melakukan wawancara eksploratoris dan focus grup untuk memperoleh masukan mengenai motivasi, sikap, dan perilaku konsumen.

2) Tahap analisis

Perusahaan menggunakan alat analisis factorial pada data untuk membuang variabel yang brkorelasi tinggi kemudian menggunakan analisis kluser untuk melakukan penetapan sejumlah segmen yang saling berbeda satu sama lain.

3) Tahap pembentukan Masing-masing kluser dibentuk dengan persyaratan perbedaan sikap, perilaku, demografis, psikografis, dan kebiasaan konsumsi media mereka.

b. Manfaat segmentasi pasar

Dengan menyatukan programprogram program yang dituju, maka menejemen dapat melaksanakan kegiatan pemasaran dengan baik dan efisien. Selaim untuk memperkuat perusahaan dalam menghadapi persaingan pasar, segmentasi pemasaran memiliki beberapa manfaat yaitu :

1) Segmentasi dapat mengidentifikasi produk baru

2) Segmentasi membantu dalam mendesain program-program pemasaran yang paling efektif untuk mencapai pelanggan yang homogeny

3) Segmentasi memperbaiki alokasi strategi daya pemasaran.

\section{c. Karakteristik segmentasi pasar}

Agar dapat bermanfaat secara maksimal maka segmen-segmen pasar harus memenuhi lima karakteristik berikut:

1) Dapat diukur

Ukuran, daya beli dan profil segmen harus dapat diukur.

2) Besar

Segmen harus besar dan menguntungkan untuk dilayani suatu segmen.

3) Dapat dijangkau

Segmen dapat dijangkau dan dilayani secara efektif

4) Dapat dibedakan

Segmen dapat dipisahkan secara konseptual dan member tanggapan yang berbeda terhadap unsur dan program bauran pemasaran.

5) Dapat diambil tindakan

Program-program yang efektif dapat dirumuskan untuk menarik dan melayani segmen yang bersangkutan.

\section{Positioning}

\section{a. Pengertian Positioning}

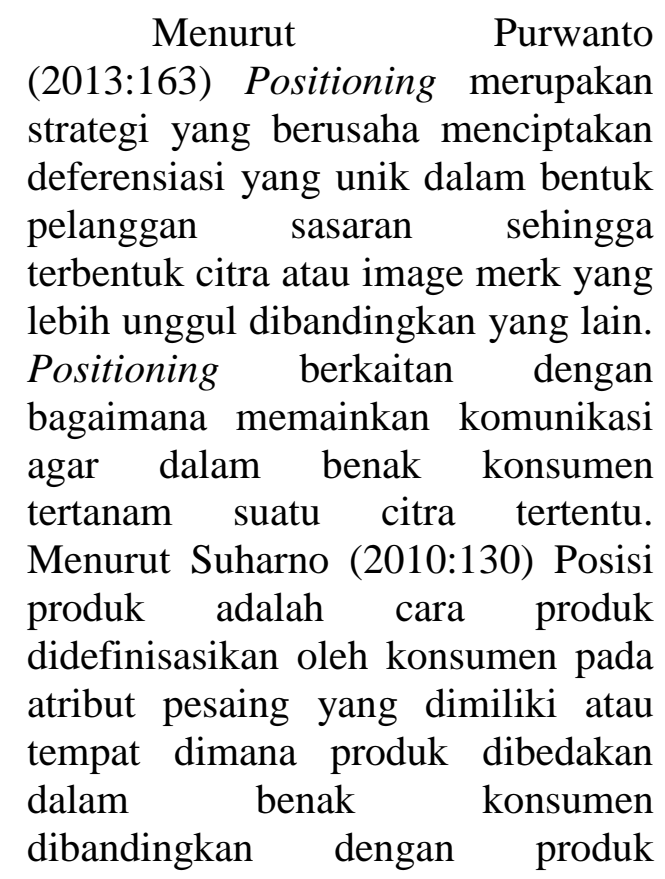


pesaing. Pembedaan dan pemosisian perlu dilakukan karna banyaknya produk dipasar.

\section{a. Langkah-langkah positioning}

Menurut Kotler dan Amstrong (2001:285) langkah-langkah positioning dalam pemasaran ada tiga yaitu:

1) Segmentasi pasar

Membagi suatu pasar menjadi suatu kelompok-kelompok pembeli yang mungkin membutuhkan produk atau bauran pemasaran yang berbeda.

2) Penargetan pasar

Mengevaluasi daya tarik masing-masing segmen pasar yang memilih satu atau lebih segmen pasar yang digarap.

3) Positioning pasar

Penentuan posisi bersaing produk dan menetapkan bauran pemasaran yang lebih rinci.

a. Stategi positioning menurut Kotler ada enam yaitu :

1) Produk diposisikan berdasarkan kebutuhan yang mereka rasakan

2) Produk diposisikan menurut skala penggunaanya

3) Produk diposisikan pengguna kelas tertentu

4) Produk diposisikan langsung berhadapan dengan pesaing

5) Produk diposisikan untuk kelas produk yang berbeda

6) Produk diposisikan menggunakan kombinasi

\section{Analisis SWOT}

\section{a. Pengertian analisis SWOT}

Menurut Freddy (2013:19) menjelaskan bahwa analisis SWOT adalah identifikasi berbagai faktor secara sistematis untuk merumuskan strategi perusahaan. Analisis ini didasarkan pada logika yang dapat memaksimalkan kekuatan (strength) dan peluang (opportunities), namun secara bersamaan dapat meminimalkan kelemahan (weakneses) dan ancaman (threats). Proses pengambilan keputusan sinergi selalu berkaitan dengan pengembangan misi, tujuan, strategi dan kebijakan perusahaan. Dengan demikian perencanaan strategi harus menganalisa faktor-faktor strategi perusahaan (kekuatan, kelemahan, peluang, ancaman).

Menurut Wikipedia, analisis SWOT singkatan dari bahasa Inggris (kekuatan/strengths, kelemahan /weaknesses kesempatan/ opportunities, dan ancaman / threats) adalah metode perencanaan strategis yang digunakan untuk suatu spekulasi bisnis. Proses ini melibatkan penentuan tujuan yang spesifik dari spekulasi bisnis atau proyek dan mengidentifikasi faktor internal dan eksternal yang mendukung dan yang tidak dalam mencapai tujuan tersebut.

\section{a. Unsur-unsur SWOT}

1) Kekuatan (Strength)

Unsur pertama dari SWOT adalah kekuatan (strength), yang dimaksud dengan kekuatan (strength) adalah semua potensi yang dimiliki perusahaan dalam mendukung proses pengembangan perusahaan, seperti kualitas sumber daya manusia, fasilitas-fasilitas perusahaan baik bagi SDM maupun bagi konsumen dan lainlain.

Yang dimaksud faktor-faktor kekuatan adalah antara lain kompetensi khusus yang terdapat dalam organisasi yang berakibat 
pada kepemilikan keunggulan komparatif oleh unit usaha dipasaran. Contoh : kekuatan pada sumber daya keuangan, citra positif, keunggulan kedudukan di pasar, dan kepercayaan bagi berbagai pihak yang berkepentingan atau yang berkaitan.

2) Kelemahan ( Weakneses )

Adalah analisis kelemahan, dimana situasi dan kondisi yang merupakan kelemahan dari suatu perusahaan pada saat ini. Tepatnya terdapat kekurangan pada kondisi internal perusahaan, akibatnya kegiatan-kegiatan perusahaan belum bisa terlaksana secara maksimal. Misalnya: kekurangan dana, karyawan kurang kreatif dan malas, tidak adanya teknologi yang memadai dan sebagainya.

\section{3) Peluang (Opportunities)}

Adalah faktor-faktor lingkungan luar atau eksternal yang positif, secara sederhana dapat diartikan sebagai setiap situasi lingkungan yang yang menguntungkan bagi suatu perusahaan atau satuan bisnis. Yang dimaksud situasi lingkungan disini adalah :

a) Perubahan dalam kondisi pesaing.

b) Hubungan antara pembeli (konsumen).

c) Hubungan dengan pemasok yang harmonis.

d) Kecenderungan penting yang terjadi dikalangan pengguna produk.

e) Identifikasi suatu segmen pasar yang belum mendapat perhatian.

4) Ancaman (threat)
Ancaman yang dimaksud dalam analisis SWOT yang bisa terjadi di lapangan adalah :

a) Harga bahan baku yang fluktuasif.

b) Masuknya pesaing baru di pasar.

c) Pertumbuhan pasar yang lambat.

d) Pelanggan yang memiliki kepekaan terhadap harga dapat pindah ke pesaing yang menawarkan harga murah.

e) Pesaing yang memiliki kapasitas yang lebih besar dan daya jangkau yang luas.

b. Manfaat analisis SWOT

Beberapa manfaat yang didapat dari analisis SWOT yaitu :

1) Sebagai panduan perusahaan untuk menyusun berbagai kebijakan strategis terkait rencana dan pelaksanaan dimasa yang akan datang.

2) Menjadi bahan evaluasi strategis dan system perencanaan perusahaan.

3) Memberikan informasi mengenai kondisi perusahaan.

4) Memberikan tantangan ide-ide baru sebagai solusi atau hasil analisa yang sudah ada.

c. Faktor-faktor mempengaruhi SWOT

yang

Menurut Purwanto (2013:260) untuk menganalisis secara lebih dalam tentang SWOT, maka perlu dilihat faktor faktor eksternal dan internal sebagai bagian penting dalam analisis SWOT, yaitu :

1) Faktor eksternal

Faktor eksternal ini mempengaruhi terbentuknya Opportunities and Threat (O dan $\mathrm{T})$. Dimana faktor ini menyangkut dengan kondisi-kondisi 
yang terjadi diluar perusahaan yang mempengaruhi dalam pembuataan keputusan perusahaan. Faktor ini mencangkup lingkungan industry dan lingkungan bisnis makro, ekonomi, politik, hukum, teknologi, kependudukan, dan social budaya.

\section{2) Faktor internal}

Faktor eksternal ini mempengaruhi terbentuknya Strengths and Weakneses (S dan W). Dimana faktor ini menyangkut dengan kondisi-kondisi yang terjadi didalam perusahaan yang mempengaruhi dalam pembuataan keputusan (decinion making) perusahaan. Faktor Internal ini meliputi semua macam manajemen fungsional :pemasar, keuangan, operasi, sumber daya manusia, penelitian dan pengembangan, system informasi manajemen dan budaya perusahaan (colporate culture).

\section{METODE PENELITIAN}

Lokasi penelitian ini bertempat pada UD. Surya Gemilang Motor yang beralamatkan di Jl. Babat Jerawat No. 8 Benowo Surabaya. Jenis penelitian yang digunakan yaitu jenis penelitian kualitatif. Dalam penelitian ini penulis menggunakan jenis penelitian kualitatif dengan pendekatan deskriptif yaitu sebuah penelitian yang bertujuan membuat pencandraan secara sistematis, faktual dan akurat mengenai faktafakta dan sifat-sifat objek penelitian.

Dalam penelitian kualitatif sebenarnya tidak menggunakan istilah populasi tetapi dinamakan oleh situasi social yang terdiri dari tempat, pelaku dan aktivitas yang berinteraksi secara sinergis. Populasi dalam penelitian ini adalah seluruh kegiatan di UD Surya Gemilang Motor Surabaya. Sampel dalam penelitian ini adalah sebagian data yang berhubungan dengan permasalahan penelitian. Dalam penelitian ini pengumpulan data dengan mengadakan pengamatan langsung pada UD Surya Gemilang Motor Surabaya. Dalam penelitian ini pihak yang di wawancarai adalah pimpinan UD Surya Gemilang Motor Surabaya dalam penelitian ini yaitu data-data pada UD Surya Gemilang Motor Surabaya. Operasional variabel adalah penarikan batasan yang lebih menjelaskan ciri-ciri spesifik yang lebih substansif dari suatu konsep. Tujuannya agar peneliti dapat mencapai suatu alat ukur yang sudah sesuai dengan hakikat variabel yang sudah didefinisikan konsepnya. Maka peneliti harus memasukkan proses atau operasionalnya alat ukur yang akan digunakan untuk kuantifikasi gejala variabel yang ditelitinya.

Menurut hubungan variabel dengan variabel yang lain maka variabel dalam penelitian ini dapat dibedakan menjadi :

a. Variabel Independen / Variabel Bebas (X)

Variabel ini sering disebut juga sebagai variabel stimulus, predictor, antecendent. Dalam bahasa Indonesia sering disebut variabel bebas. Variabel adalah merupakan variabel yang mempengaruhi atau yang menjadi sebab perubahannya atau timbulnya variabel dependen (terikat). Dalam SEM (Structural Equation Modeling) atau Pemodelan Persamaan Struktural, 
variabel independen disebut sebagai variabel eksogen (Sugiyono,2015:61).

Dalam penelitian ini yang ditulis didalam variabel bebas adalah:

1. Segmentasi pasar $\left(\mathrm{X}_{1}\right)$ yaitu proses membagi pasar keseluruhan suatu produk atau jasa yang bersifat heterogen ke dalam beberapa segmen dimana masing-masing segmen cenderung bersifat homogeny dalam segala aspek. (Tjiptono,2008:69)

2. Positioning produk $\left(\mathrm{X}_{2}\right)$ yaitu strategi yang berusaha menciptakan deferensiasi yang unik dalam bentuk pelanggan sasaran sehingga terbentuk citra atau image merk yang lebih unggul dibandingkan yang lain. (Purwanto,2013:163)

b. Variabel Dependen / Variabel Terikat (Y)

Variabel ini sering disebut juga sebagai variabel output, kriteria, konsekuen. Dalam bahasa Indonesia sering disebut variabel terikat. Variabel terikat adalah merupakan variabel yang dipengaruhi atau yang menjadi akibat, karena adanya variabel bebas. Dalam SEM (Structural Equation Modeling) atau Pemodelan Persamaan Struktural, variabel independen disebut sebagai variabel indogen. (Sugiyono,2015:61). Variabel terikat dalam penelitian ini adalah volume penjualan (Y) yaitu jumlah total yang dihasilkan dari penjualan barang. (Rangkuti,Freddy.2013)

\section{PEMBAHASAN}

Dari hasil analisis SWOT yang dilakukan oleh UD Surya Gemilang Motor berdasarkan analisis SWOT yang dilakukan UD Surya Gemilang Motor Surabaya memiliki kekuatan yang dipakai pada strategi tertentu serta memanfaatkan peluang yang tepat secara bersamaan meminimalkan menghindari kelemahan dan ancaman yang ada posisi ini menguntungkan perusahaan dengan memperbiki kondisi diatas rata-rata kemampuan UD Surya Gemilang Motor Surabaya dapat mengendalikan para pesaing. Dari hasil analisis SWOT skor kekuatan (strength) 2,34, kelemahan (weakness) 0,68, peluang (opportunity) 2,5 , ancaman (treath) 0,7. Dari diagram SWOT diatas dapat dilihat dari selisih nilai skor kekuatan dan kelemahan nilai skor lebih tinggi kekuatan dengan selisih $+1,66$. Sedangkan nilai skor selisih peluang dan ancaman nilai skor tertinggi yaitu peluang dengan selisih $+1,8$. Sehingga dengan jelas menunjukkan bahwa UD Surya Gemilang Motor talah berada pada jalur yang tepat dengan terus melakukan strategi agresif untuk meningkatkan penjualan.

Dari empat kemungkinan strategi alternative yang diperoleh diatas, strategi yang tepat yang digunakan oleh UD Surya Gemilang Motor Surabaya dalam meningkatkan penjualan yaitu perumusan strategi yang efektif akhirnya diperoleh strategi agresif SO yaitu strategi kekuatan yang memanfaatkan peluang yang dimiliki perusahaan yaitu : 
1. Lebih meningkatkan sistem menegemen yang efektif dan efisien.

Dalam mencapai tujuan perusahaan untuk meningkatkan penjualan maka UD Surya Gemilang Motor harus lebih efektif meningkatkan menejemen marketing dengan cara menjalin hubungan baik dengan konsumen dan juga perusahaan lain agar memudahkan pemasaran pada perusahaan supaya pemasararan dapat efektif dan efisien sehingga peningkatan penjualan dapat tercapai.

2. Lebih meningkatkan SDM agar tetap dipercaya konsumen.

Untuk lebih memperererat hubungan dengan konsumen, maka SDM yang dimiliki harus lebih meningkatkan pelayanannya supaya konsumen dapat percaya dan citra perusahaan tetap ada pada konsumen dan tentunya konsumen dapat bertambah agar penjualan meningkat.

3. Menentukan segmen pasar dan positioning produk.

Dalam hal ini UD Surya Gemilang Motor harus menentukan segmen pasar yang dituju agar tepat guna dan berusaha menciptakan citra produk yang baik dalam benak konsumen dengan cara memberikan pelayanan yang bagus agar pemasaran yang dilakukan dapat maksimal sehingga dalam rangka meningkatkan penjualan.

\section{KESIMPULAN DAN SARAN}

Berdasarkan dari hasil pembahasan analisa atas masalah yang telah dikemukakan sebelumnya, maka diperoleh kesimpulan sebagai berikut :

1. Penerapan strategi segmentasi pasar dan positioning produk dengan menggunakan pendekatan analisis SWOT untuk peningkatan penjualan pada UD. Surya Gemilang Motor Surabaya yaitu dari hasil analisis SWOT skor kekuatan (strength) 2,34 , kelemahan (weakness) 0,68, peluang (opportunity) 2,5 , ancaman (treath) 0,7. Dari diagram SWOT diatas dapat dilihat dari selisih nilai skor kekuatan dan kelemahan nilai skor lebih tinggi kekuatan dengan selisih $+1,66$. Sedangkan nilai skor selisih peluang dan ancaman nilai skor tertinggi yaitu peluang dengan selisih $+1,8$. Sehingga dengan jelas menunjukkan bahwa UD Surya Gemilang Motor Surabaya telah berada pada jalur yang tepat dengan terus melakukan strategi agresif untuk meningkatkan penjualan.

2. Kebijakan penerapan strategi segmentasi pasar dan positioning produk dengan pendekatan analisis SWOT untuk peningkatkan penjualan pada UD. Surya Gemilang Motor Surabaya yaitu perumusan strategi yang efektif akhirnya diperoleh strategi agresif SO yaitu strategi kekuatan yang memanfaatkan peluang yang dimiliki perusahaan yaitu :

a. Lebih meningkatkan sistem menejemen yang efektif dan efisien 
b. Lebih meningkatkan SDM agar tetap dipercaya konsumen

c. Menentukan segmen pasar dan positioning produk

Dari penelitian ini dan kesimpulan diatas dapat diberikan beberapa saran sebagai berikut :

1. Untuk dapat meningkatkan penjualan produk, maka UD Surya Gemilang Motor perlu menentukan segmen pasar mana yang dituju agar tepat guna mempertahankan citra image baik pada konsumen agar konsumen tidak beralih ke pesaing lain.

2. Dalam pemasaran yang dilakukan oleh UD Surya Gemilang Motor perlu memperbaiki kelemahankelemahan seperti lebih meningkatkan sistem menejemen yang efektif dan efisien dan bekerja sama dengan perusahaan yang lain agar semakin kuat.

3. Untuk peneliti selanjutnya, hendaknya menambahkan faktorfaktor lain yang lebih lanjut dengan topik yang sama tentang segmentasi pasar, positioning produk dan analisis SWOT sehingga diperoleh penelitian yang lebih baik.

\section{DAFTAR PUSTAKA}

Kotler dan Keller, 2004. Manajemen Pemasaran. Indeks, Jakarta.

Kotler dan amstrong, 2001. Marketing. Indeks, Jakarta

Purwanto, 2013, Komunikasi Bisnis. Erlangga.

Rangkuti, Freddy, 2013. Analisis SWOT. PT Gramedia Pustaka. Jakarta.

Sugiyono. 2015. Metode Penelitan Pendidikan. Alfabeta, Bandung.

Suharno, 2010. Marketing in Practice. Graha Ilmu, Yogyakarta.

Swastha dan Irawan, 2005. Menejemen pemasaran Modern. Liberty, Yogyakarta.

Tjiptono, Andi, 2008. Strategi Bisnis Pemasaran. Andi, Yogyakarta. https://id.wikipedia.org/wiki/Analisis SWOT.online

http://www.kajianpustaka.com/2013/ 03/strenghts-weakness-opportunities .html.online 